\title{
The history of dermatology and dermatopathology in different countries - Iran
}

\section{Nooshin Bagherani ${ }^{1 *}$ and Bruce R Smoller ${ }^{2}$}

${ }^{1}$ Dermatologist at Dr. Nooshin Bagheran's office, Taha Physicians' building, P.O. Box: 6414715878, Khoramshahr, Khuzestan Province, Iran ${ }^{2}$ Professor and Chair, Department of Pathology, Professor, Department of Dermatology, University of Rochester, School of Medicine and Dentistry, USA

\begin{abstract}
About Iran
Iran, also known as "Persia" is located in Western Asia. Its area is about $1,648,195 \mathrm{~km}^{2}(636,372 \mathrm{sq} \mathrm{mi})$. It is the world's 17 th most crowded country, and has 78.4 million inhabitants. The main language of Iranians is Persian (Parsi or Farsi). Its geostrategic importance is related to: A- its central location in Eurasia and Western Asia, and Bits proximity to the Strait of Hormuz [1].

Iran is bordered by Armenia, Azerbaijan, Kazakhstan and Russia (the two latters across the Caspian Sea) to the northwest, Turkmenistan to the northeast, Afghanistan and Pakistan to the east, Turkey and Iraq in the west, and the Persian Gulf and the Gulf of Oman to the south. Its climate ranges from arid or semiarid, to subtropical [1].

Historically, the Medes organized the first Iranian government in the 7th or 8th century BC. After this government, subsequent empires include the Achaemenids (559-330 BC), Arsacids (250 BC - 226 AD), and the Sassanids (226 - $652 \mathrm{AD})$ [2].

One of the world's oldest civilizations was founded in Iran by the Proto-Elamite and Elamite kingdom in 3200-2800 BC. In 550 BC, Cyrus the Great founded the largest empire that the world has yet seen, Achaemenid Empire (Figures 1 and 2). At that period, Iran comprised major portions of the ancient world, extending from parts of the Balkansin the west to the Indus Valley in the east. Following the attack of Alexander the Great, Achaemenid Empire was collapsed in 330 BC [1].
\end{abstract}

In $633 \mathrm{AD}$, Rashidun Muslims invaded Persia. Afterward, for many

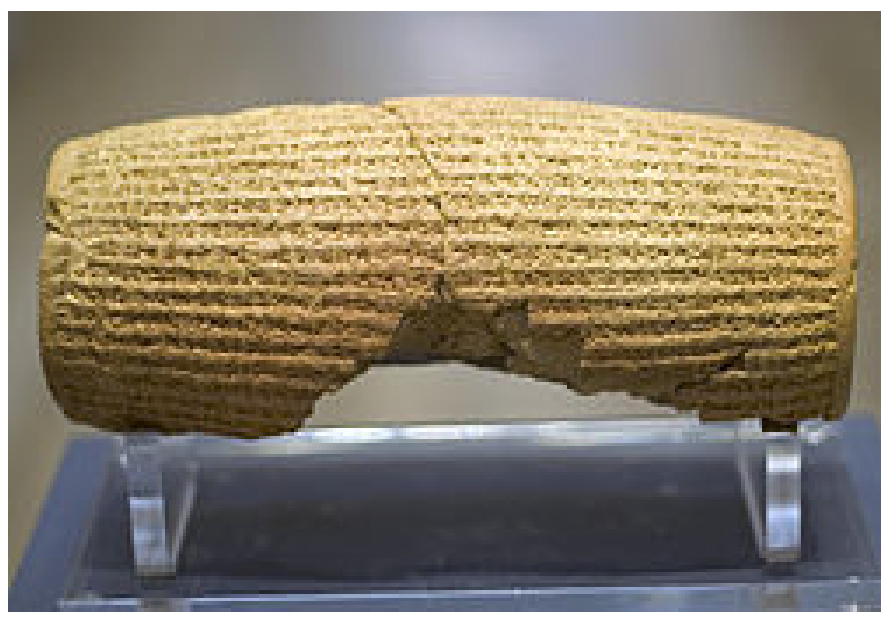

Figure 1. The Cyrus Cylinder (Persian: شوروك روشنم), an ancient clay cylinder, belongs to 6 th century $\mathrm{BC}$. years Arabic was the main language in Iran [1]. Hassan Sabbah, Naser Khosro and Ferdowsi were the great persons who endeavored so much for making and remaining Persian language alive [3]. In spite of many politicial obstacles, Iran played a pivotal role in subsequent years (the Islamic Golden Age) with having many influential scientists, scholars, artists, and thinkers such as Omar Khayyam, Zakariya Razi, Ibn Sina and Al-Biruni. The "Islamic Golden Age" which begun from the year 786, was ended in 1258 by Mongol invasion [1].

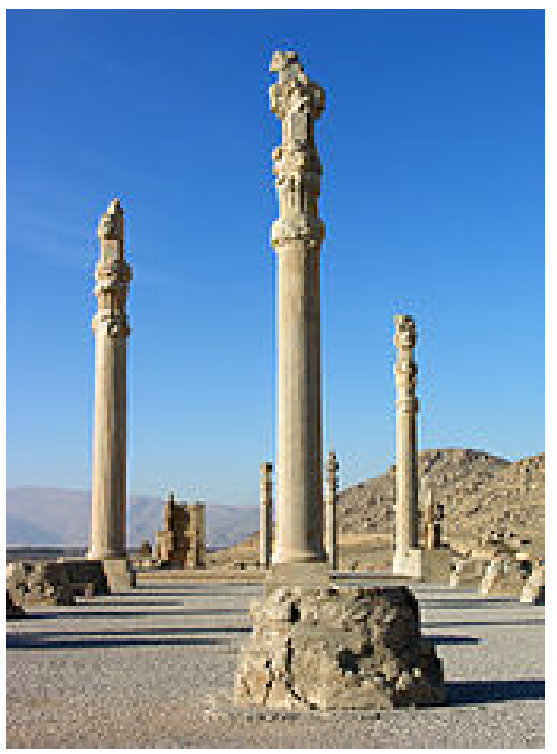

Figure 2. Ruins of the Achaemenid palace of Persepolis located in Shiraz.

Correspondence to: Nooshin Bagherani, Dermatologist at Dr. Nooshin Bagheran's office, Taha Physicians' building, P.O. Box: 6414715878, Khoramshahr, Khuzestan Province, Iran, Tel: 00989165828461; E-mail: nooshinbagherani@yahoo.com

Special Issue: Dermatology History in Different Countries

Nooshin Bagherani, M. D.

Dermatologist at Dr. Nooshin Bagheran's office, Taha Physicians' building, P.O.Box: 6414715878, Khoramshahr, Khuzestan Province, Iran; Email: nooshinbagherani@yahoo.com

Bruce R. Smoller, M. D.

Chair, Department of Pathology and Laboratory Medicine

Professor, Department of Pathology and Laboratory Medicine Professor, Department of Dermatology

University of Rochester School of Medicine and Dentistry, USA E-mail: smollerbrucer@uams.edu

Published: December 20, 2015 
Before the Arab invasion, the main religion of the Iranian people was Zoroastrianism. The main messages and philosophy of Zoroaster (between 625 and 550 BCE) the Persian Prophet- were "Good Words", «Good Thoughts», and "Good Deeds" (Figure 3).

\section{Ancient Medicine and Dermatology in Iran}

The medical history in Iran refers to the period of Pathaha who lived near the Khorezm and the first Aryan doctor was named "Trita" who is equal to "Asklpyvs" to the Greeks and "Skvlapyvs" to the Romans. He used herbal extracts in treating disorders. In the Pahlavian-written books, it has been stated that Trita also did surgical procedures. Not only is Trita well-known by Persians but also by Indians; it shows that this Persian physician is related to the period in which Iranian Aryan hadn't be separated from Indian Aryan.

After Trita, another Aryan physician named "Yama" who lived in area of Ryavyzh could diagnose patients with skin, bone, and teeth disorders from healthy cases. People who lived in this area used sun radiation for being healthy.

The oldest documents about Persian medicine are "Avesta" and other religious Zoroastrian texts such as "Denkart" and "Bundahishn". These documents focused on hygiene, public health, and prevention of contagious diseases as the most significant points in the field of medicine. In "Avesta", the religious book of the Zoroastrians in Avestan language, the name of several medicinal herbs such as basil, chicory, sweet violet, and peppermint have been stated [2].

During the Achaemenids era, medicine was very developed in Iran because of proximity to Greece. The Achaemenids founded several medical schools in their territory such as the school that was built in Sais in ancient Egypt by the order of Darius (521-485 BC), one of the Achaemenids kings. At that period, many Greek and Egyptian physicians were employed in the Achaemenids court, among whom we can name Ctesias. Later, at the period of the Arsacids era, many Greek books were translated into Persian language [2].

Some historians believe that in the world's history of medicine Hippocrates (460-355 BC) from Greece was the first person who systematically organized medicine and separate medicine from magic and talisman. After him, Galen (129 AD) built the first school for autopsy and his thoughts were the basis for scientists for years. However, in the "history of medicine in Iran", Dr. Najmabadi believed that Zarathustra's medical is mismore ancient that Greek medicalisms $[1,4]$. Cyril Elgood in his book entitled "Medical History of Persia" has confirmed Najmabadi's thought; he believed that Iranians have taught the Greeks the basis of the thing known as Greek medicine [1].

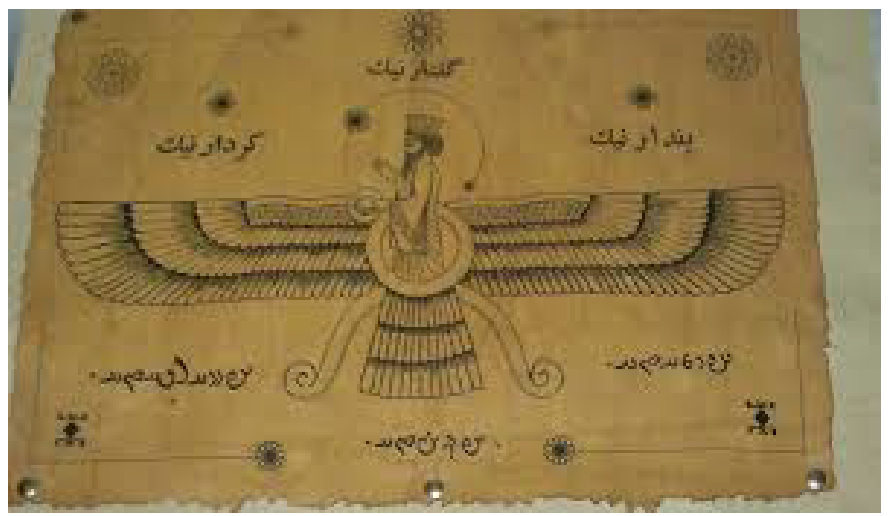

Figure 3. The Faravahar, the symbole of Zoroastrianism.

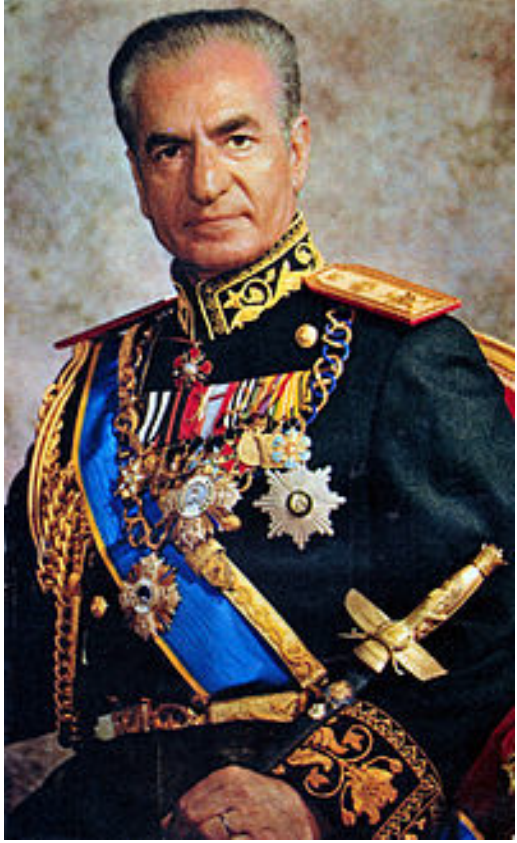

Figure 4. Mohammad Reza Pahlavi.

During the war between Greece and Iran, medical works of Hippocrates and other Greek physicians were carried away to Iran. Then Persian physicians were able to revive Greek medicalisms in Academy of Gundeshapur by translating these works. In the golden Islamic period, with the revival of Greek medicalisms in Iran, many internationally well known figures like Zakariya Razi, and Ibn Sina developed Iranian medicalisms like four-nature ism. In this period, in comparison with Europe, Iran had much more therapeutic centers and hospitals which were equipped by developed wards, libraries, and drug stores [1]. One of the advances in this period was the organization of the mobile hospitals carried by camels and other animals [5].

Dermatology history in Iran roughly mirrors the history of medicine [6]. Clinical manifestations and treatment of many cutaneous disorders have been described in ancient Persian books. In the "Avesta", disorders such as scabies, leprosy, and vitiligowere described $[4,6]$. The existing texts of the Avesta were derived from a single master copy, which was produced by Sassanids era's (224-651 CE) collation [1]. At the middle era of Iranian medicine, many comprehensive books and papers were written by Persian physicians with interest in dermatologic conditions. For instance, Zakariya Razi, and Ibn Sina are two the most important figures in this ground [1,6].

It appears that the first specialized book in the ground of skin disorders was written by Zakariya Razi, but western scientists believe that Ali ibn al-'Abbas al-Majusi was the founder of dermatology in the world [7].

One of the golden period in the field of medical advancement is Pahlavi kingdom (1925-1979) [1]. Building and reconstruction of novel medical universities and associations with great international medical universities owed Reza Shah and his son, Mohammad Reza Shah, the only two kings of this dynasty (Figure 4). Among them we can name Pahlavi University in Shiraz, Jundishapur University in Ahvaz, Tehran University in Tehran, and Mashhad University in Mashhad, which are the best, high-ranked universities in Iran. 


\section{History of some of famous medical centers in ancient Iran}

\section{Academy of Gundeshapur}

The academy of Gundeshapur, which was organized in the city of Gundeshapurin southwestern Iran during late antiquity, was one of the three Sassanids' centers of education (Ctesiphon, Resaina, Gundeshapur) [1].

The city of Gundeshapur,which was one of the four major cities of Khuzestan Province, was the intellectual center of the Sassanids Empire. At the end of the third century AD, this city was rebuilt by "Shapur I", one of Sassanids kings, after defeating the Byzantine Emperor Valerian and conquering Antioch, one of ancient Greek city. Then Shapur called it "Veh-AZAndev-Shapur", that in Pahlavi language it means "Shapur better than Antioch". Later, its name was changed to Gundeshapur [2].

The first foundation of the academy of Gundeshapur refers to the time of arrival of the Aryan people; then it was rebuilt in 309-379 AD by "Shapour II" for keeping Greek and Roman captives to use their specialties. At first, in this academy Sassanides' kings decided to collect Zoroastrian books especially their scientific sections that had been taken away by Alexander's attack upon Iran [1,2].

In this academy, scholars devoted to medicine, philosophy, theology and science were trained [1]. In the field of medicine, a combination of Hippocrates's (460-377 BC), Galen's (130-199 AD), Persian's and Indian's traditions were taught. Many students and scholars from all over the world were attracted to this center [2]. Based on "The Cambridge History of Iran", this academy was the most important medical center of the ancient world during the 6th and 7th centuries [1].

When in the year of 632, Arabs attacked Iran, the academy of Gundeshapur was in the most fruitful situation. After this period, most of its mentors immigrated to the academy of Baghdad [1].

\section{Gundeshapur Hospital}

In the history of medicine, Gundeshapur Hospital was the first teaching hospital in the world. Dr. C Elgood believed that the credit for the whole hospital system mainly belongs to Persia. It appears that other hospitals, which were established later such as the first medical center in Baghdad, were built based on this hospital [2].

The activity summit of the Gundeshapur Hospital, was in the 6th century $\mathrm{AD}$, which continued till $869 \mathrm{AD}[2]$.

\section{The Polytechnic and Science School of Dar-al-Fonoon}

In 1850, the first novel training medical center was organized by Amir Kabir, one of chief ministers to Naser al-Din Shah Qajar, as one of the sections of the Polytechnic and Science School of Dar-alFonoon (Figure 5) [1,6]. Jakob Eduard Polak, an Austrian physician and Focckette, an Italian pharmacist were the first mentors that started training in this center [1].

In the $70^{\text {th }}$ anniversary of the foundation of Dar-al-Fonoon, the branches of medicine and pharmacology were separated. Charles Oberling (1895-1960), the famous French pathologist, Amir Alam and Javad Ashtiani are among the past presidents of medical school of Daral-Fonoon [1].

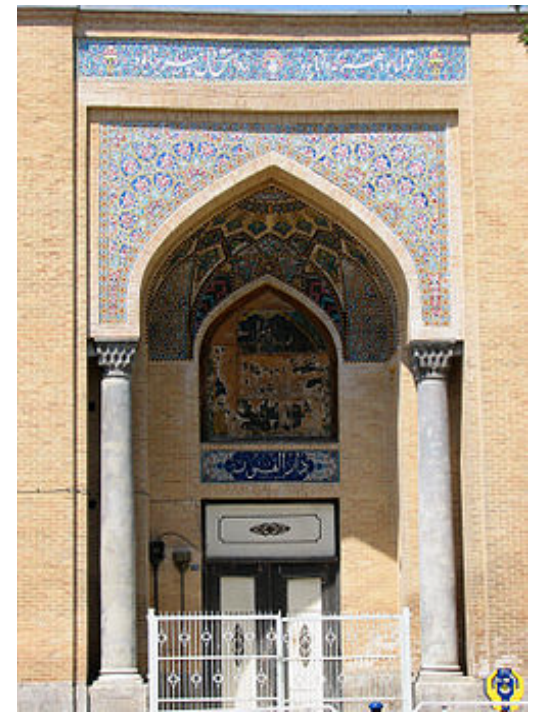

Figure 5. The Polytechnic and Science School of Dar-al-Fonoon.

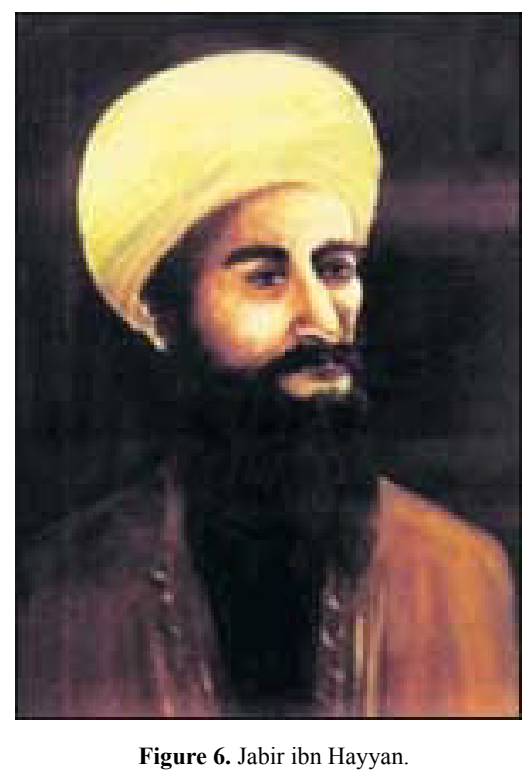

\section{The most famous Persian figures playing important roles in the medicine and dermatology}

\section{Jabir ibn Hayyan (Geber)}

Jabir (721-815) (Figure 6) was a prominent Iranian polymath, a chemist, alchemist, astronomer, astrologer, engineer, geographer, philosopher, physicist, and pharmacist and physician.He is known as the Father of early chemistry. He discovered hydrochloric acid, nitric acid, citric acid, and acetic acid [1].

\section{Ali ibn al-'Abbas al-Majusi (Haly Abbas or Masoudi)}

Haly Abbas (died in 982-994) (Figure 7) was a Persian physician and psychologist, who was born in Ahvaz. "Kitab al-Maliki" or "Complete Book of the Medical Art" is his textbook in the fields of medicine and psychology. It has been said that this book is more systematic and concise encyclopedia than Razi's Hawi (see below), and more practical than Avicenna's The Canon of Medicine (see below). In 


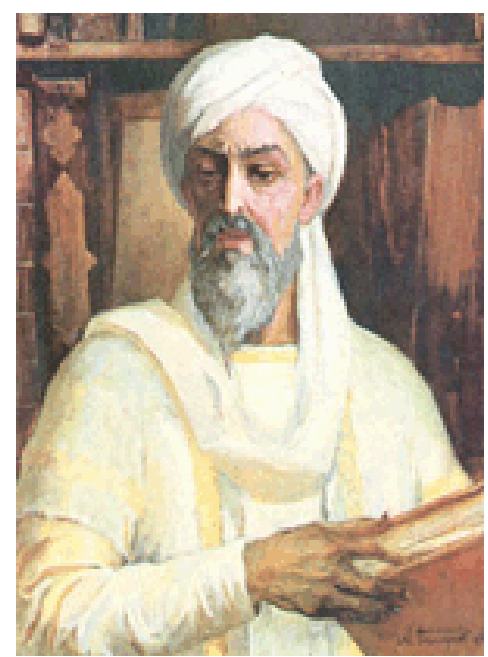

Figure 7. Ali ibn al-'Abbas al-Majusi (Haly Abbas or Masoudi).

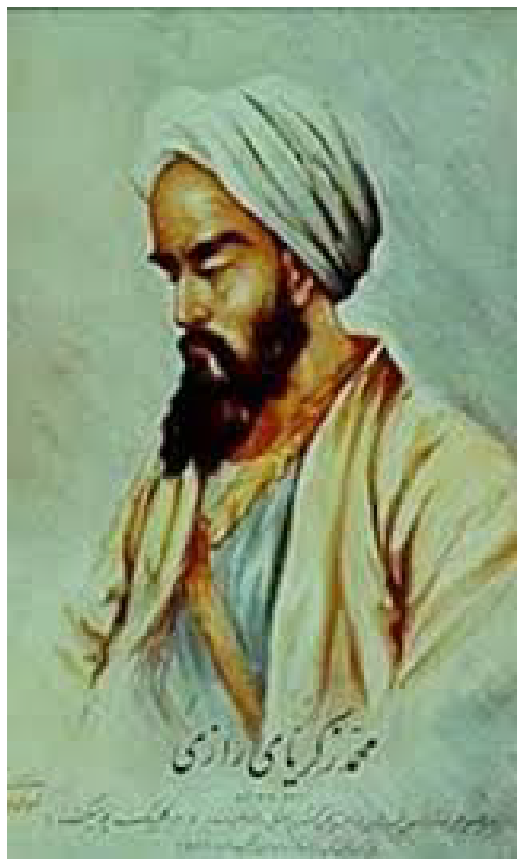

Figure 8. Muhammad ibn Zakariya al-Razi.

this book, Haly Abbas have emphasized a healthy relationship between physicians and patients, and the significance of medical ethics [1]. Haly Abbas described treatment of general and specific skin disorders in two papers, separately [7].

Some western scientists believe that Haly Abbas is the founder of the dermatology science in the world [7]. He was a pupil of Shaikh Abu Maher Musa ibn Sayyār. He is considered one of the three greatest physicians of the Eastern Caliphate of his time. He was the physician of Emir 'Adud al-Daula Fana Khusraw of the Buwayhid dynasty. The Emir founded a hospital at Shirazin Persia, and the Al-Adudi Hospital in Baghdad, where Haly Abbas workedin [1].

\section{Muhammad ibn Zakariya al-Razi (Rhazes or Rasis)}

Razi (Figure 8) was a Persian physician, polymath, alchemist and chemist, and philosopher. Razi who is known as the doctor's doctor, the father of pediatrics, and a pioneer of ophthalmology, was born in Rey (near Tehran) in 854 and died there in 925. With more than 200 manuscripts, he is famous particularly for numerous advances in medicine.

For the first time, Razi discovered sulfuric acid and alcohol. He supported experimental medicine and in this ground he was a successful doctor. For many years, Razi was as chief physician in Baghdad and Rey hospitals [1]

Razi wrote a pioneering book about smallpox and measles and gave his opinion about acquired immunity $[1,6]$. He also described the clinical manifestations of atopy and allergic rhinitis [6].

Razi's medical works such as "Al-Mansuri" and "al-Hawi" profoundly influenced medical education in the Latin West and medieval universities. As medicine instructor, Razi attracted students of all backgrounds and interests. Edward Granville Browne, a British orientalist, introducedhim as "probably the greatest and most original of all the physicians, and one of the most prolific as an author" [1].

In the field of "Ethics of medicine", Razi has invaluable recommendations to the physicians. He believed that in advanced cases of incurable cancer and leprosy, physicians should not be blamed [1].

\section{Ibn Sina (Avicenna)}

Ibn Sina (Figure 9) who was born in 980 in Afšana, a village near Bukhara (in present-day Uzbekistan) and died in June 1037 in Hamadan, was a great Persian polymath, jurist, and physician. He lived in the circumstances in which the translations of Greco-Roman, Persian, and Indian texts were studied extensively (the Islamic Golden Age) [1]

Ibn Sinahas 40 written works on medicine. "Kitab al-Shifa" (The Book of Healing) - a philosophical and scientific encyclopedia, and " $A l$ Qanun fi al-Tibb" (The Canon of Medicine) - a medical encyclopedia are two of the most important books which written by Ibn Sina. These 2 books were standard medical texts at many medieval universities in Europe and the Islamic world from the 12 th to the $17^{\text {th }}$ century. Hebrew version of "Avicenna's Canon of Medicine" was seen in Naples in 1491, and its Arabic version in Rome in 1593. It was reprinted in New York in 1973 [1].

Although Ibn Sina's method in medicine was not essentially different from that of his predecessor, Rhazes (Razi), the Canon of Ibn Sina is distinguished from the Al-Hawi or Summary of Rhazes by its more logical method [1].

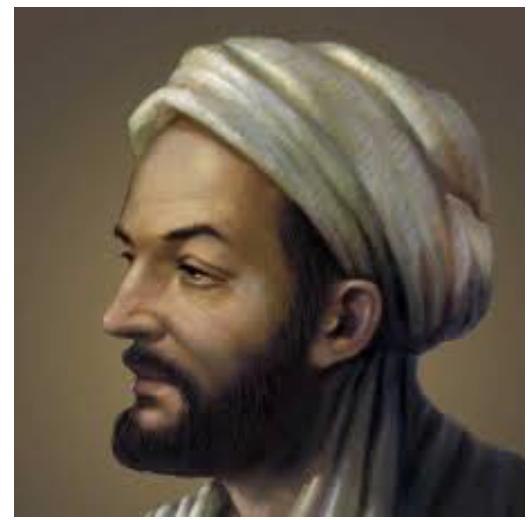

Figure 9. Ibn Sina, a Persian Physician with a great reputation in the world. 
In addition to philosophy, medicine, mathematics, and physics, Ibn Sina was an expert in psychology, astronomy, alchemy, geography and geology, Islamic theology, logic, and poetry and wrote works on them. Ibn Sina also has studies on medical herbs [1].

"The Canon of Medicine" is famous for its complete explanation of contagious diseases, sexually transmitted diseases, and testing of medicines. In this book, quarantine has been introduced as a way for limiting the spread of infectious diseases. Ibn Sina believed in the miasma theory of disease. He agreed with Aristotle (and disagreed with Hippocrates) that tuberculosis was a contagious disease, a fact that was not universally accepted in Europe for several centuries afterward. Furthermore, in this book Ibn Sina described paths for testing medicine, the process that today we know it as clinical trials [1]. The description of elephantiasis, leprosy, various hair and nail disorders, and vitiligo, and pemphigus has been attributed to Avicenna $[6,8]$.

\section{Novel dermatology and dermatopathology}

Under the influence of the western medicine, dermatology in Iran transitioned into modernism. The European physicians such as Jacob E Polak of Bohemia were visiting professors at the Polytechnic and Science School of Dar-al-Fonoon in Tehran [6,9]. Furthermore, many young medical students who graduated from the Dar-al-Fonoon, traveled to Europe for completing education. These young physicians after returning to Iran had a great impact on the formation of modern medicine and dermatology [6].

After the establishment of "University of Tehran", in 1939, the first departments of dermatology in Iran were founded by Prof. Mohammad Maleki and Prof. Mohammad Sadri in Razi and Sina Hospitals, respectively [7]. There were only 5 departments of dermatology in Iran until 1980. These were located in the Universities of Tehran, Melli, Shiraz, Mashad, and Isfahan. Programs for training residents in dermatology were gradually established through structured programs of didactics and clinical rotations [6]. We can remember figures like Prof. Amir H Mehregan and Prof. Manouchehr Sodaify who played a great role in formation of the modern aspects of dermatology and dermatology education in Iran particularly in "Pahlavi University".

During the last 2 decades, the number of medical schools has been increased in Iran, among which 11 universities have been approved for having 4-year dermatology residency training programs. These programs are closely monitored by the Iranian board of dermatology specialty that its members are picked up from the most prominent academic dermatologists in Iran [6].

\section{History of some of the novel famous medical centers in Iran}

\section{Tehran University of Medical Sciences and Razi Hospital}

Tehran University of Medical Sciences (Figure 10) was established in 1934 [6] in where Prof. Mohammad Ali Maleki founded the first Iranian department of dermatology in $1943[6,10]$. Razi Hospital is the location of the Tehran University-related department of dermatology. This is the most ancient and specialized dermatology center in Iran. In 1957, the first program for training dermatology residents was done by Iranian dermatologists who graduated from foreign universities [11].

Razi Hospital was established in 1940 as a general hospital. Two years later, the wards of internal medicine, surgery, obstetrics, and urology were founded in this hospital. In 1941, this hospital was annexed to the Tehran University of Medical Sciences, and the wards

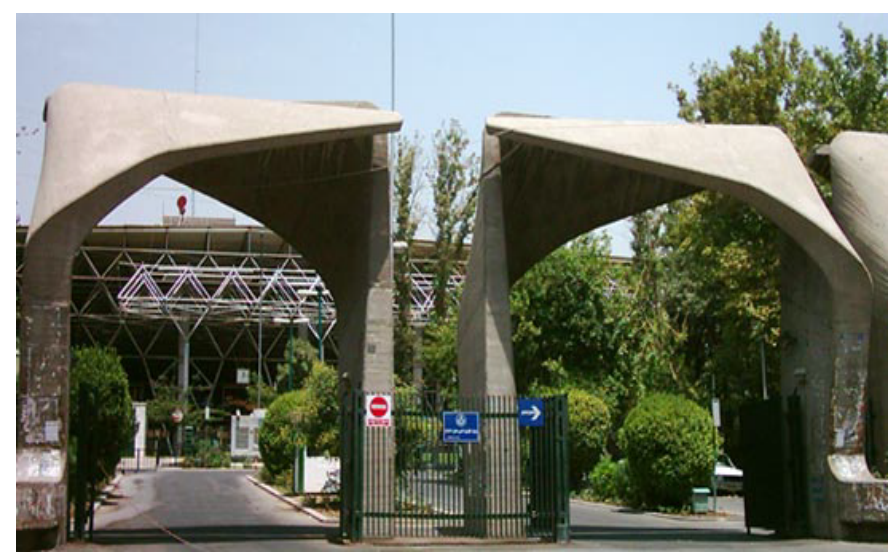

Figure 10. Tehran University.

Table 1. Chairs of dermatology department of the Tehran University of Medical Sciences from 1949 till now.
Mohammad Ali Maleki (1949-1966)
Mohaghegh Yazdi (1966-1971)
Amir Pasha Mohagheghi (1971-1976)
Vadud Seyedi (1976-1979)
Mahdi Ravaghi (1979-1986)
Parvin Mansouri (1986- 1996)
Zahra Hallaji (1996-2002)
Farshad Farnaghi (2002-2004)
Cheyda Chams (2004-2008)
Zahra Hallaji (2008-2011)
Mir Hadi Aziz-Jalali (2011-2012)
Zahra Ghodsi (2012-2015)

of pediatrics, toxicity, radiology, dermatology and venereology were added to this hospital. In 1943, Prof. Mohammad Maleki was assigned as chair of the dermatology and venereology ward of this hospital. In 1949, Maleki continued his work with this hospital as dermatology mentor [10].

In 1969, Razi hospital was specialized to dermatology [10]. Today, in addition to the treatment of patients with skin disorders, many cosmetics procedures are done in this hospital [11].

The chairs of dermatology department of the Tehran University of Medical Sciences from 1949 till now have been summarized in Table 1.

\section{Mashhad University of Medical Sciences}

Mashhad University of Medical Sciences, which is located in Mashhad, the capital city of Razavi Khorasan province in northeastern Iran, was established in 1949 [1]. Before its establishment as a separate university with different faculties, Mashhad Medical Center was founded by Dr. Mohammad Taghi Radpour and his colleagues in 1940. In 1942-1971, Dr. Khalili and Dr. Sadr started their collaboration with this center. Radpour played a great role in founding Mashhad University of Medical Sciences-related dermatology department. $\mathrm{He}$ established the first separate dermatology ward in 1948 in Imam Reza hospital, Mashhad. In those years, the only laboratory tests were simple ones for diagnosing leishmaniasis, scabies and fungal elements. Later, 
with Dr. Ahmad Alavi's efforts, the dermatopthology department was organized. Among the figures who played great roles in optimizing the dermatology department of the Mashhad University of Medical Sciences, we can name Prof. Seyyed Kazem Mostofi and Dr. Zahra Fazel [12].

\section{Shiraz University of Medical Sciences (University of Pahlavi)}

Shiraz, which is located in the southwestern part of Iran [1], is fifth largest city of Iran and capital of the Fars province [13]. This city is one of the oldest cities of ancient Persia with an age over 4000 years. Shiraz is the hometown of poetry, art, wine and flowers [1]. The "University of Pahlavi" which changed its name to the "Shiraz University of Medical University" was organized in this city in 1946 (Figure 11). Its architect was Minoru Yamasaki, who also was the architect of World Trade Center in New York, USA.

With the invitation of the president of the University of Pennsylvania by Mohammad Reza Pahlavi, the "Pahlavi University" was put under the authority of the University of Pennsylvania, an association that continued until the end of Pahlavi Kingdom. The "Pahlavi University" was also named as the sister of the "Princeton University". This was the first university of Iran for which its educational documentations were international [1].

The Dermatology department of "Pahlavi University" was founded in 1974. Prof. Christopher Griffiths was the first founder of this department. The first dermatology resident in this department was Manouchehr Sodaify, who continued his education in dermatology in London University. After returning to Iran, Sodaify made great attempts towards optimizing the educational situation in this department. $\mathrm{He}$ played a great role in holding associations between this department and Universities of London and Liverpool.

\section{Isfahan University of Medical Sciences}

Isfahan or Sepahan is the third biggest city of Iran and is the capital of Isfahan Province. It is located near the center of Iran. Isfahan University of Medical Sciences, which is in Isfahan, is one of the most prestigious Iranian medical schools. It was founded in 1946 [1].

The Dermatology Department of the Isfahan University of Medical Sciences was organized in 1956.

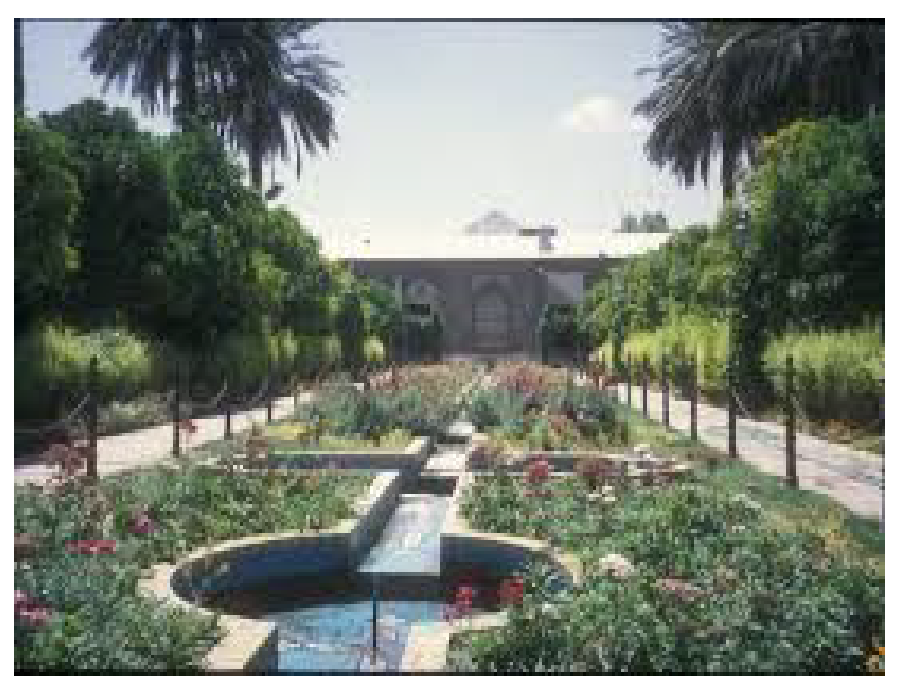

Figure 11. Shiraz University of Medical University (University of Pahlavi).

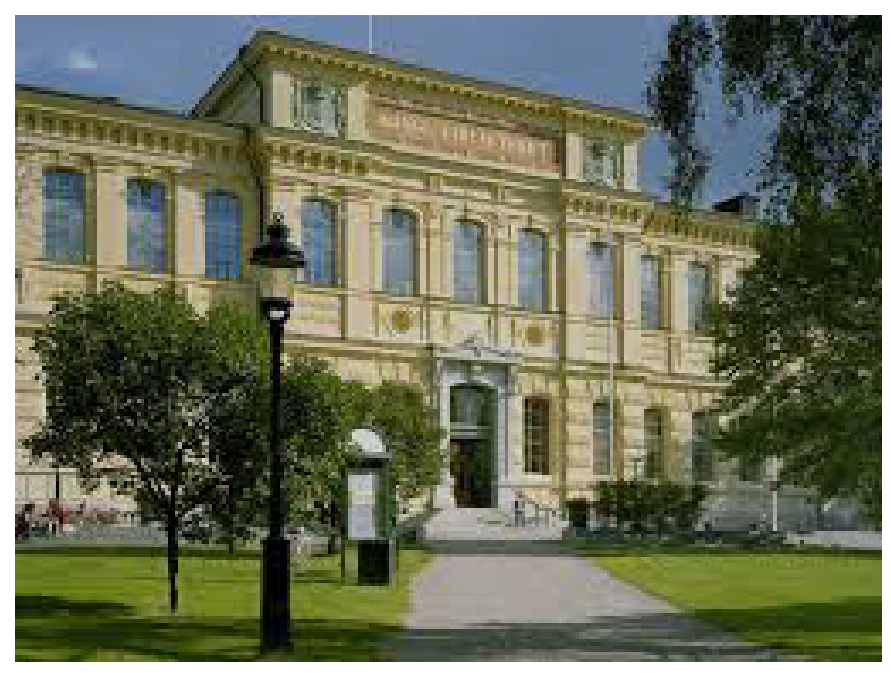

Figure 12. Ahvaz JundishapurUniversity of Medical Sciences.

Tabriz University of Medical Sciences (University of Azerbaijan)

Tabriz, which is the capital of East Azerbaijan Province, is the most populous city in the northwest part of Iran. In 1275 when Marco Polo traveled to this city through the Silk Road, he described Tabriz as a pretty city surrounded by so beautiful gardens [14]. Eugene Aubin, Embosser of France in Iran in 1906-1907, who had a visit from Tabriz confirmed the beauty of this city [15]. The University of Azerbaijan, which later changed its name to Tabriz University of Medical Sciences, was founded in Tabriz by the autonomous Azerbaijan People's Government under the presidency of Jafar Pishevari in 1946 [1].

The Dermatology department of the Tabriz University of Medical Sciences is one of the oldest dermatology departments in Iran that recruited the first residents of dermatology in 1967. Among the figures who played great roles in foundation of this department we can name Professor Ganjavian, Professor Sadr, Professor Sheikholeslam-zadeh, and Professor Khosro Shahi. Today, Professor Mahdi Aminia is chair of this department [16].

\section{Ahvaz Jundishapur University of Medical Sciences}

Ahvaz is the capital city of Khuzestan Province, which is located in southwestern Iran on the banks of Karoon River. Its history refers to Darius king from Achaemenid Empire. Ahvaz Jundishapur University of Medical Sciences (Figure 12), which is located in Ahvaz, was established in 1955. Indeed, this university is a revived reincarnation of the ancient Academy of Gundeshapur that existed in the same area in antiquity [1].

The dermatology department related to the Ahvaz Jundishapur University of Medical Sciences was founded by Dr. Aishwaryia Acharya in 1969. After Acharya, this department was closed for a while; Then, Dr. Monireh Osuli revived the department in 1986. Professor Reza Yaghoobi, Dr. Mohammd Omidian, Dr. Mohammad Ali Mapar and Dr. Mohammad Radmanesh have had and have great role in optimizing resident-training programs in this department [17].

\section{Shahid Beheshti Universityof Medical Sciences (The National (Melli) University of Iran)}

In 1959, the National University of Iran which then its name was changed to Shahid Beheshti University was organized by Ali 
Sheikholislam in Tehran to be the first private university in Iran. The Schools of Medicine and Dentistry were established in 1961 [1].

The dermatology department of the Shahid Beheshti University was founded in 1973 in Loghman Hakim Hospital [1]. Professor Parviz Toosi had an important role in optimizing the educational program in this department.

\section{Iran University of Medical Sciences (Imperial Medical Center)}

Imperial (Shahanshahi) Medical Center, which is one of the most prestigious medical centers in Iran was founded in 1974. Its building was designed by William Pereira and Associates. Later its name was changed to Iran University of Medical Sciences. Professor Habib Ansarin played a great role in optimizing the educational plans for the dermatology department associated with this university.

\section{Research and Training Center for Skin Diseases and Leprosy}

The "Research and Training Center for Skin Diseases and Leprosy" was organized by Yahya Dowlati in 1993. This center has a close relationship with the World Health Organization (WHO) and conducts many studies in the ground of clinical assessment and vaccine trials for leishmaniasis. This center also supervises basic science and laboratory researches in the fields of dermatopathology, microbiology, parasitology, pharmacology, and keratinocyte biology. Moreover, this center serves educational programs to dermatology residents and has relationships with dermatology departments to promote researches in the dermatology field [6].

\section{Skin Research Center}

Skin Research Center, which is related to the Shahid-Beheshti University of Medical Sciences, was founded by Parviz Toosi and his colleagues in 2000. The goals of this center include: academic studies in the grounds of diagnosis and treatment of skin disorders; offering training programs to students and patients; linkage with other domestic and international research centers to optimizing academic studies in the ground of skin diseases; epidemiologic studies on skin disease to prepare a complete data bank; and holding many national and international meetings [18].

\section{Skin and Stem-cell Research Center}

Skin and Stem-cell Research Center, which is a Tehran University of Medical Sciences -related organization, was established in 2011. The goal of this organization is conducting basic and practical researches in the ground of preventing and treating skin disorders, especially chronic resistant cutaneous conditions, burning, chronic ulcers, diabetic foot, etc. In this center, the molecular and stem cell-related techniques are used for the treatment of these skin disorders. Now, Dr. Mohammad Ali Nilforoushzadeh is director of this research center [19].

\section{Dermatology and Leishmaniasis Research center}

The "Dermatology and Leishmaniasis Research center" which is related to the Isfahan University of Medical Sciences, was founded in 2000. Mohammad Ali Nilfroushzadeh and Ali Asilian had great role in organization of this center. Dr. Nilfroushzadeh was the first president of this center.

The most famous Persian figures playing important roles in novel dermatology, and dermatopathology

\section{Mohammad Maleki}

Mohammad Maleki graduated from the Dar-al-Fonoon and completed his medical degree at the Faculté de Medicinede, in Paris, France. His thesis on the "use of gold minerals in the treatment of syphilis" under the supervision of Professor Milliam was impressive [6]. The novel dermatology and dermatopathology in Iran owes his effort. The dermatology department in Tehran University of Medical Sciences was founded by his serious efforts.

\section{Mohammad Taghi Radpour}

Mohammad Taghi Radpour (1909-) is one of Persian figures who played a great role in advancing novel dermatology in Iran [1]. He graduated in the dermatology specialty from Saint Louis Hospital, in Paris.

Radpour was one of the founders of medical school in Mashhad in 1940, in where he started his work as mentor in dermatology. $\mathrm{He}$ established a separate ward for infectious and sexually-transmitted diseases in the main hospital in Mashhad in where the patients with skin disorders were also served. Before this date, there was no dermatology-specified ward in Mashhad and patients with skin conditions were treated in internal medicine wards. Later, the first dermatology department was organized by Radpour in 1948 in Imam Reza hospital, Mashhad [12].

\section{Amir Hossein Mehregan}

Amir H. Mehregan (Figure 13) (1931-2000) was one of the most famous and impressive figure in dermatology and dermatopathology in Iran and even in the world $[6,7]$.

In 1948, Mehregan entered the Tehran University of Medical Sciences. In 1955, he went to the Unites States of America in order to continue his post graduate training in dermatology in the Skin and Cancer Hospital of Philadelphia and the Wisconsin University in Madison. During those years, he became interested in skin pathology and collected pathological slides [20].

Visiting Professor Hermann Pinkus in 1958 was a golden date in Mehregan's academic life; then Mehregan passed a two-year fellowship under the tutelage of Dr. Pinkus at the Wayne State University, Medical School in Detroit. Mehregan and Pinkus jointly published many papers and the book "A Guide to Dermatopathology"; the title of the latter changed to "Pinkus' Guide to Dermatohistopathology" by Mehregan for reviving the memory of Pinkus after his death [20].

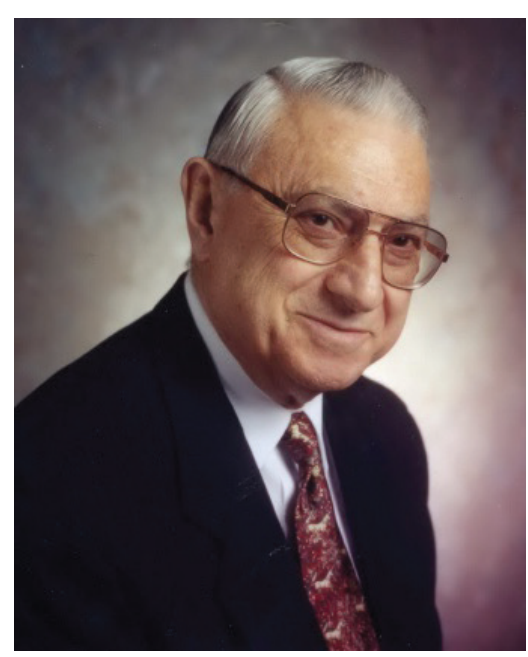

Figure 13. Professor Amir H. Mehregan. 
After completing his studies in dermatology and dermatopathology in the United States, Mehregan came back to Iran and went to Shiraz in 1962 [6]. He played a great role in establishing novel aspects of dermatology and dermatopathology at the Pahlavi University [20]. A few years later, he returned to the United States to continue his productive scientific career. During his academic life in the United States, he retained his association withthe Iranian academic dermatology community $[6,20]$.

\section{Manouchehr Sodaify}

Manouchehr Sodaify (Figure 14) is professor of dermatology and one of the great figures who played important roles in optimizing dermatology education in Iran. He became interested in dermatology when he was a medical student in Razi Hospital (Tehran), where Dr. Naser Sadeghi and Wadood Seidi, professors of dermatology in Tehran University, gave him this impression that dermatology had been a branch of medicine that needed a great knowledge for a good and precise diagnosis.

Following his graduation in medical school he went to Shiraz for his military service in 1950. He started his residency program in internal disease at Pahlavi Medical School. There, he studied skin problems in different patients. In his third year of residency, he got the chance for a scholarship for London University, following a scientific contract between the two universities.

He started his diploma course in London which was followed by another course in Liverpool University; meanwhile he was head of dermatology department in the Pahlavi University on his return to Iran. Then, he went to Michigan University, the United States to see Professor Mehregan and got trained in dermatopathology, followed by passing a course of leprosy in New Orleans. Sodaify also had the opportunity to go to France for post graduate training in laser, cosmetology and hair transplantation.

During his academic life, he trained about 140 dermatologists. Among them some were assigned as academic members in dermatology departments in different universities in Iran.

He was chair of dermatology department for 25 years, as well as member of Iranian board of dermatology, and the president of Shiraz

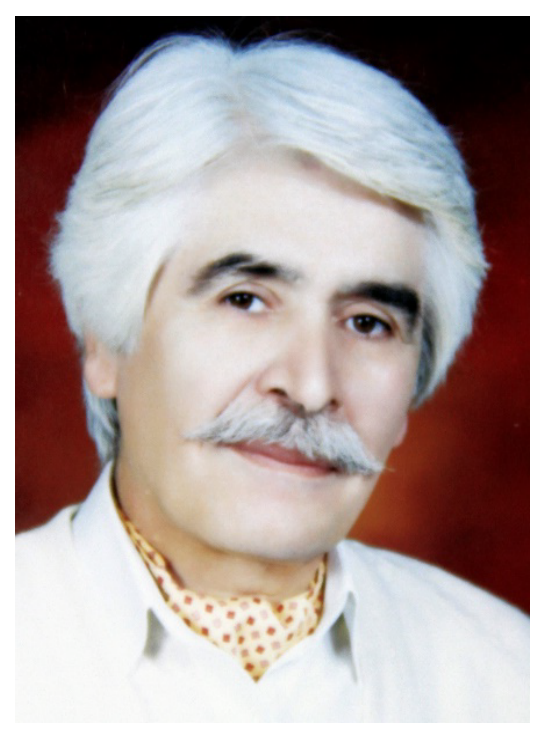

Figure 14. Professor Manouchehr Sodaify.

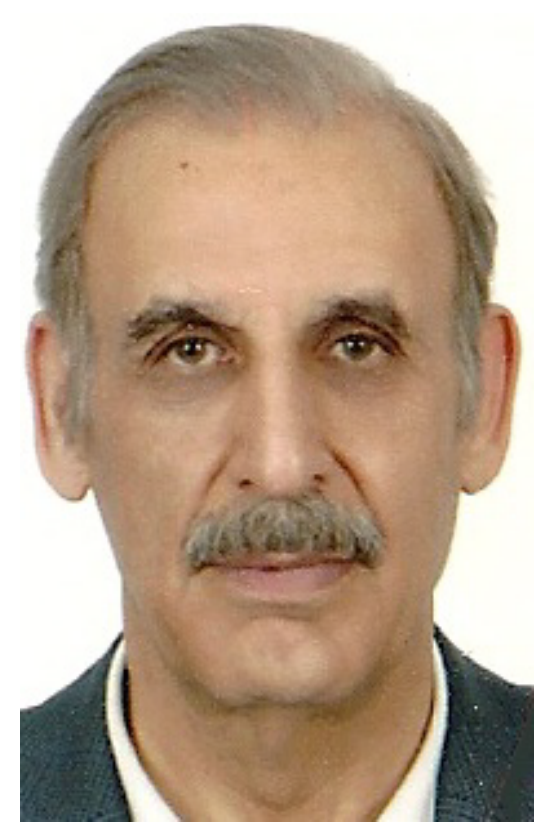

Figure 15. Professor Habib Ansarin.

Dermatology Scientific Association. Because of his internal medicinal, as well as his dermatological activities, he has had opportunity to take part and present papers in different domestic as well as international congresses. He also wrote chapters in dermatology textbooks. At present, he is teaching medical students of Kazeroon University in his private clinic.

\section{Habib Ansarin}

Habib Ansarin was born in 1940 in Tabriz (Figure 15). In 1958 he was accepted as medical student in the Tabriz University. In 1967, he started his residency in dermatology in the Razi Hospital, and in 1970 he graduated in specialty of dermatology and venereology as the best student. In that year, he was assigned as the director of the first dermatology ward in Hedayat Hospital related to "Ta'min Ejtemaei" Organization.

Professor Ansarin started his academic life with the teaching dermatology of students of colleges related to the Health Ministry and "Ta'min Ejtemaei" Organization in 1971 and then in Imperial (Shahanshahi) Medical Center and Ghods college. In 1981, he was assigned as the chair of dermatology department related to the Iran University of Medical Sciences.

Ansarin played great role in optimizing educational situation in the field of dermatology. He was a member of committee for selecting medical interns and dermatology residents. He also was a member of the Iranian Board of Dermatology Specialty.

Amongst his great honors, he was selected as the best mentor in the Iran University of Medical Science (2001), as the best physician by Iranian Medical Council (2002), as the best mentor by the students of the Iran University of Medical Science (2003), and as the best mentor of the Tehran University of Medical Sciences (2011).

Ansarin is member of the committee for assessing medical documents from foreign countries, member of the committee for assessing generic drugs related to Health Ministry, member of the committee for planning educational programs for dermatology residents, editor-in chief of the journal related to Iranian Society 
of Dermatology, member of the editorial board of " Novel Medical Treatment" Journal, reviewer and the member of the journals related to the Medical Universities of Iran, Tehran, Shahid Beheshti and Azad and member of Iranian Academy of Medical Sciences.

\section{Cheyda Chams Davatchi}

Cheyda Chams Davatchi (1940-) is one of the figures who has played a great role in establishing novel dermatology and dermatological education in Iran. She graduated from Medical University of Paris, France. In 1970-1972, she was chair of dermatology clinic in the hospital of Boucicaut in Paris. Now she is professor of dermatology in the Tehran University of Medical Sciences [21,22].

Chams is president of Pemphigus Research Center in the Razi Hospital and council member of the International Society for Behçet's Disease. She has published many papers on pemphigus and Behçet's Disease [22].

\section{Parviz Toosi}

Parviz Toosi played great role in establishing dermatology department in the Shahid Beheshti University of Medical Sciences. In 2000, Skin Research Center in relation with this university was founded by Toosi and his colleagues.

\section{Yahya Dowlati}

Yahya Dowlati (1934- ) was born in Famenin, Hamedan Province. In 1959, he graduated in pharmacology and then in 1966 he completed his education in general medicine. He worked for a while in army. Then he traveled to the United States and achieved his specialty in dermatology and dermatopathology [23].

After returning to Iran, Dowlati restarted his work in army but in this time as a dermatologist. He played a great role in the foundation of "Hospital of Sanaye Nezami"-an army-related hospital- which opened in 1974.

Dowlati devoted much effort to preventing and treating leprosy in Iran. He is the president of "Iranian Society of Dermatology" and "Research and Training Center for Skin Diseases and Leprosy" [23].

\section{Seyyed Kazem Mostofi}

Seyyed Kazem Mostofi (1938-) was born in Khoramshahr. He graduated in dermatology specialty from the Tehran University in 1970. He started his work as official associate professor and then professor at the University of Mashhad. He was the chair of the dermatology department of this university for over 16 years. He also is as a faculty member of Iranian Board of Dermatology specialty [24].

\section{Reza Yaghoobi}

Reza Yaghoobi (1952-) is one of the great figures that has an important role in establishing novel dermatology and dermatopathology in Iran. He graduated in dermatology from The National University of Iran. Then, he went to Ahvaz and assigned as chair of dermatology department of the Ahvaz Jundishapur University of Medical Sciences. Yaghoobi had a great role in reviving this department after a relatively long period that this department was inactive. He is member of the Iranian Board of Dermatology Specialty.

In the years 2001 and 2005, Yaghoobi was awarded as the best national physician. He is one of the best in diagnosis of uncommon and very rare dermatologic disorders in Iran.

\section{Mohammad Omidian}

Mohammad Omidian who is the mentor of dermatology in the Ahvaz Jundishapur of University, played a great role in establishing dermatology department of this university.

\section{Mohammad Ali Mapar}

Mohammad Ali Mapar is chair of dermatology department of the Ahvaz Jundishapur of University. Beside Yagoobi and Omidian, he played an important role in organizing this department. Dr. Mapar is one of the best dermatologists in diagnosis of uncommon and rare dermatologic disorders.

\section{Mohammad Radmanesh}

Mohammad Radmanesh is one of the best Iranian dermatologists in the field of laser and laser surgery. He has published many papers on role of lasers for treatment of many dermatologic disorders.

\section{Ali Abbasi}

Ali Abassi is the best figure in the field of hair transplantation in Iran and one of the best in this field in the world. He graduated in dermatology from the National University of Iran in 1993. In 2003, he succeeded to pass a fellowship in hair transplantation in the United States. He has published many works on hair transplantation. $\mathrm{He}$ introduced a novel method for decreasing post-procedural swelling after hair transplantation by injection of a solution entitled "Abbasi's solution" which is used by many dermatologists in the world. By introducing this solution, Abbasi made a great impression in hair transplantation.

\section{Mohammad Ali Nilfroushzadeh}

Mohammad Ali Nilfroushzadeh had a great role in the foundation of "Skin and Stem-cell Research Center" and "Dermatology and Leishmaniasis Research center". He has published many works on leishmaniasis [25].

\section{Reza F Ghohestani}

Reza F Ghohestani is one of the successful Persian dermatologists

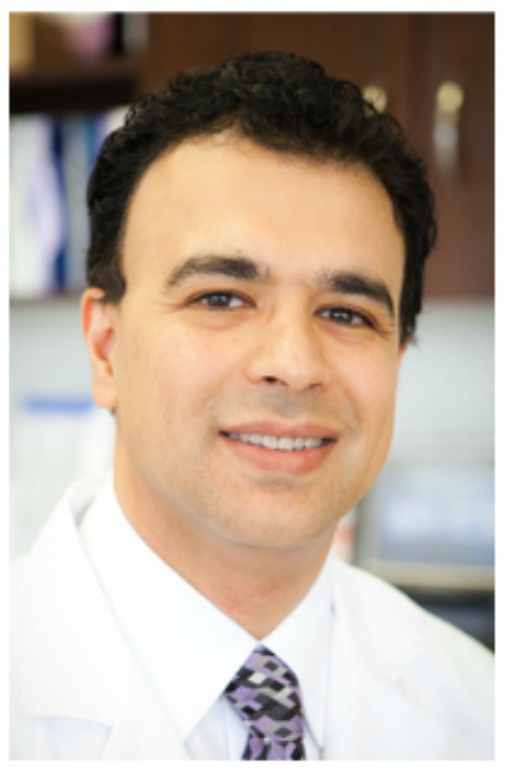

Figure 16. Professor Reza F Ghohestani. 
with an international reputation (Figure 16). He completed his internship in surgery at Pennsylvania Hospital, University of Pennsylvania, Philadelphia, PA followed by a residency in dermatology at Thomas Jefferson University. With deep interests in skin, Ghohestani obtained a master's degree in Cutaneous Biology, Cosmetology, and Skin Pharmacology, and a Ph.D. in Skin Immunobiology from Claude Bernard University, France. He was mentored by professors Jean Thivolet (Founder of Modern Dermatology Research in France), Alan Claudy, and Jean Francois Nicolas. Later, he did a fellowship in molecular biology and skin genetics at the Nice School of Medicine, France, and was mentored by professors Jean-Paul Ortonne and Gim Meneguzzi.

Ghohestani served as the principal investigator and team leader for many years at various Academic Institutes. His research was funded by the National Institute of Health, the Dermatology Foundation, and the American Skin Association.

Ghohestani was on Faculty as an Assistant and then Associate Professor at Thomas Jefferson University (1998-2007) before moving to San Antonio, Texas where he was the Chief and Associate Professor of Dermatology and Cutaneous Surgery at the University of Texas Health Science Center at San Antonio. He is currently Director of Texas Institute of Dermatology in San Antonio, Texas and a Professor of Dermatology at Tuoro University.

Ghohestani's outstanding work and dedication to excellence have earned him numerous honors and peer recognitions including the American Skin Association Career Award, the Dermatology Foundation Career Award, the Charles Grupper Prize by the French Society of Dermatology, the Stelwagon Award for Best Publication by the College of Physicians of Philadelphia and the Commitment to Professionalism award by the Pennsylvania Medical Society, Razi Prize in Medicine and Kharazmi International Award in Medical research both discerned by presidents of iran.

Ghohestani is skilled in the art and science of skin care, dermatology and surgery. He continually searches for and implements the best treatment options for his patients. He has published over 100 papers and abstracts in medical journals. He also served as the co-editor of the "European Journal of Dermatology" from 2001-2008. His group identified a novel autoimmune disease characterized by presence of auto-antibodies to a 5 and a 6 chains of type IV collagen.

\section{Keyvan Nouri}

Keyvan Nouri is one of the successful Persians who has an international reputation in the dermatology field (Figure 17). He is a Tenure Professor of dermatology, ophthalmology, and otolaryngology. $\mathrm{He}$ is director of Mohs, dermatologic and laser Surgery and director of surgical training for the Department of Dermatology at the University of Miami. Nouri completed a combined undergraduate and medical education program (MMEDIC) at Boston University in 1993, and went on to pursue a dermatology residency at the University of Miami (UM). After residency, he completed a procedural dermatology fellowship in Mohs Micrographic Surgery, Dermatologic, Laser, and Cosmetic Surgery at New York University.

He is the editor-in-chief of the "Lasers in Medical Science Journal" and the editor of 7 well known textbooks including "Techniques in Dermatologic Surgery", "Skin Cancer", "Complications in Dermatologic Surgery", "Lasers in Dermatology and Medicine", "Mohs Micrographic Surgery", "Dermatologic Surgery: Step by Step" and "Laser Dermatology Handbook". He also serves as editor of the "Cells to Surgery Quiz"

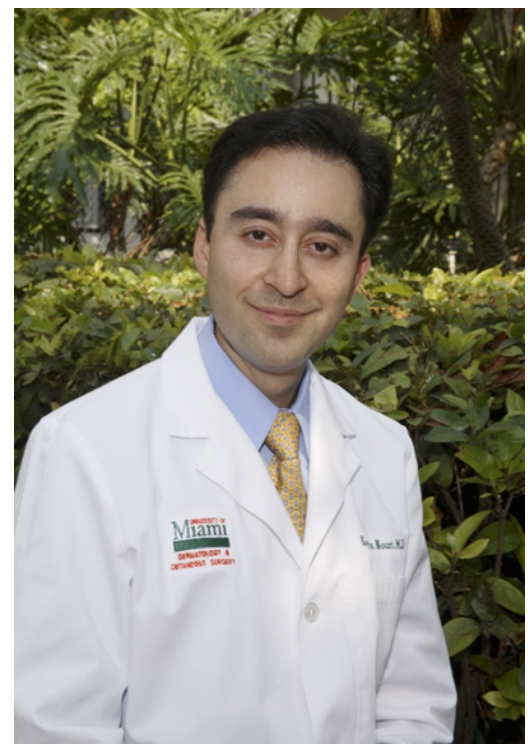

Figure 17. Professor Keyvan Nouri.

Section of the" Journal Investigative Dermatology", section editor for "Dermatologic Surgery" section of the "International Journal of Dermatology", and a member of the surgical advisory board for JAMA Dermatology. He is the author of over 185 peer-reviewed scientific articles, 119 book chapters, and many other publications. He has been an invited speaker, moderator, and presenter more than 475 times at various national and international meetings. He was the first person who introduced Mohs Micrographic surgery to Iran.

Nouri has completed and performed many clinical research trials in the areas of lasers for treatment of scars, lasers for treatment of skin cancers, attempting to define the peak absorption of basal cell carcinomas, and the treatment of acute wounds with artificial skins and lights. He has collaborated with basic scientists in the department in a number of translational studies looking for markers in non-melanoma skin cancers. One of his current research interest is study on "Sun safety behaviors in the younger population and trying to intervene in order to prevent skin cancer prevention".

As a member of the UM staff, some of Dr. Nouri's numerous contributions are being Vice-Chair of University of Miami Medical Group, Director of the Graduate Education Specialty Training (GEST) Program for the Department of Dermatology and Cutaneous Surgery since 2004.

Besides his leadership roles within UM, he also has various leadership roles for the Florida Society of Dermatologic Surgeons (past president and current program co-chairman), American Society of Dermatologic Surgery (past program co-chairman of mastery of lasers course), American College of Mohs Surgery, the American Society of Lasers in Medicine and Surgery, and the International Society of Dermatology (one of the current vice-presidents and previous cochairman for continental meetings).

\section{Iranian Society of Dermatology}

In 1956, Maleki and his colleagues founded the "Iranian Society of Dermatology" (ISD) [6].

Annually, the ISD organizes several domestic and international dermatology meetings. Furthermore, the society has a close 
relationship with other international societies and institutions such as the "International Society of Dermatology".

The "Iranian Journal of Dermatology ", which is the ISD-related journal, is supervised by Yahya Dowlati as editor in chief, who also is the current president of the society [6].

Today, the Iranian Society of Dermatology has over 800 members, all of whom are dermatologists who graduated from Iran Universities or, if having graduated from other countries' Universities, their academic certificate has been approved by Iran Universities [6].

\section{Iranian Dermatology journals}

In the following we have listed some of the most important Dermatology Journal in Iran:

- $\quad$ Iranian Journal of Dermatology

- $\quad$ The journal related to the Research and Training Center in Skin Diseases and Leprosy

- $\quad$ The Journal of Dermatology and Cosmetics

\section{References}

1. https://en.wikipedia.org/wiki/.

2. Azizi MH (2008) Gondishapur School of Medicine: the most important medical center in antiquity. Arch Iranian Med 11: 116-119.

3. Paul Aamir (2008) The Lord of Alamut: Hasan Sabbah. Badraghe-ye Javidan Press, Iran.

4. Nadjmabadi M (1992) History of Medicine in Iran [in Persian]. (2ndedtn). Iran Tehran University Press, Iran.

5. Mikaeili H, Yazdchi M, Taleb A, Rajabnezhad MR (2015) History of military medicine in Islam and Iran. GMP Review 18: 2
6. Mortazavi H, Dowlati Y, Dowlati B (2001) A Brief History of Dermatology in Iran Arch Dermatol 137: 936-937.

7. http://www.irsod.com/

8. Nadjmabadi M (1992) Bibliography of Rhazes [in Persian]. (2ndedtn). Iran Tehran University Press, Iran/

9. Polak JE (1989) Persien: das Land und seine Gewohner [in Persian]. Djahandari K, trans. Tehran, Iran Kharazam Publications.

10. http://razidermgroup.tums.ac.ir/

11. http://www.irandarman.com/

12. http://www.mums.ac.ir/dermatology/fa/history1

13. Schwartz R, Ghohesani (2009) Dermatology at Shiraz University of Medical Sciences Iranian J Dermatol 12: 141

14. Marco Polo (1854) The travels of Marco Polo: the Venetian. G. Bell \& sons.

15. Eugene A. La perse d'aujourd hui Iran mesopotamie. Translated by Ali Asghar Saeidi. Pulished by Nashr-e-Elm.

16. http://medfac.tbzmed.ac.ir/?pageid=206

17. http://irandoctors.persianblog.ir/post/8/

18. http://src.sbmu.ac.ir/?siteid=146\&pageid $=5684$

19. http://311.rc.research.ac.ir/Forms/Introduction.aspx

20. Azizi MH, Bahadori M, Dabiri S, Meymandi S (2015) Remembering Professor Amir Hossein Mehregan (1931-2000); the great Iranian dermatopathologist; Arch Iranian Med 18: 139-142.

21. http://www.mihanpezeshk.com/

22. www.citytomb.com/biography/

23. http://www.ettelaat.com/new/

24. http://www.negahmedia.ir/mob/media/show_video/7738

25. http://sdlrc.mui.ac.ir/

Copyright: $\bigcirc 2015$ Bagherani N. This is an open-access article distributed under the terms of the Creative Commons Attribution License, which permits unrestricted use, distribution, and reproduction in any medium, provided the original author and source are credited. 